Thorax, 1978, 33, 705-710

\title{
Reproducibility and comparison of responses to inhaled histamine and methacholine
}

\author{
E F JUNIPER, P A FRITH, C DUNNETT, D W COCKCROFT, AND F E HARGREAVE \\ From the Regional Chest and Allergy Unit, Department of Medicine, St Joseph's Hospital and \\ McMaster University, Hamilton, Ontario, Canada
}

Juniper, E F, Frith, P A, Dunnett, C, Cockcroft, D W, and Hargreave, F E (1978). Thorax, 33, 705-710. Reproducibility and comparison of responses to inhaled histamine and methacholine. The efficiency of a standardised inhalation test procedure was studied by examining the reproducibility of responses to histamine and methacholine. In addition, the responses to the two agents were compared. Each set of duplicate tests was carried out on a separate day within one week, and all factors known or presumed to influence responses were carefully controlled. The results were expressed as the provocative concentration of the agent causing a $20 \%$ fall in forced expired volume in one second $\left(\mathrm{PC}_{20}\right)$. Responses to histamine and methacholine were highly reproducible (coefficients of determination $\left[\mathrm{r}^{2}\right]=0.994$ and 0.990 respectively).

Responsiveness to histamine correlated closely with responsiveness to methacholine $\left(\mathrm{r}^{2}=0.85\right)$. There was a small but significant cumulative dose effect with methacholine $(P<0.01)$ but not with histamine. Side effects of throat irritation, flushing, and headache were more frequent with histamine than methacholine, and were dose-related. The high level of reproducibility indicates the efficiency of the test procedure. The similar severity of effects by agents with different mechanisms of action suggests that the primary cause of non-specific bronchial hyperreactivity lies at the level of bronchial smooth muscle.

Non-specific bronchial reactivity is the term used to indicate the responsiveness of the airways to chemical mediators, such as histamine, acetylcholine, and prostaglandin $F_{2} \alpha$, or to the synthetic analogues of acetylcholine, such as methacholine and carbachol. Its measurement is becoming increasingly important in clinical practice, epidemiology, and research.

Non-specific bronchial reactivity is measured by inhalation tests, usually with histamine or methacholine. In the past different methods have been used, making critical analysis of results difficult. Recently Chai et al (1975) and Orehek and Gayrard (1976) have emphasised the importance of the standardisation of tests. Standardisation requires consideration of the many different factors that will influence the results.

In this study we have standardised a simple inhalation test using histamine and methacholine. We have investigated the efficiency of the method by examining the reproducibility of responses over a short period. In addition we have compared the responsiveness to each agent and investigated the possibility of cumulative dose-effects and recorded side effects.

\section{Subjects and methods}

\section{SUBJECTS}

The patients were adults with asthma attending the regional chest and allergy unit. All had episodic dyspnoea or wheezing and documented variation in forced expired volume in one second $\left(\mathrm{FEV}_{1}\right)$ of more than $20 \%$, either spontaneously or after medication. None had features of any other respiratory disorder.

Normal adults were volunteers from hospital staff. They had no present or past symptoms of rhinitis, asthma, or other respiratory disorder. They were non-smokers, non-atopic, and had normal spirometry. Non-atopic implied that they had no early wheal and flare responses to prick tests with extracts of Alternaria, Cladosporium, Aspergillus fumigatus, cat, dog, feathers, horse, housedust, Dermatophagoides farinae, egg white, milk, nuts, shellfish, tree pollen, grass pollen, and 
ragweed pollen. Informed signed consent was obtained.

\section{INHALATION TESTS}

Inhalation tests were carried out by the method described for histamine by Cockcroft et al (1977a). Aerosols of physiological saline, histamine acid phosphate or methacholine were delivered into a face mask from a Wright nebuliser with an output of $0.13 \mathrm{ml} / \mathrm{min}$ and aerosol particles of $1.3 \mu \mathrm{m}$ mass median diameter and $2.11 \mu \mathrm{m}$ geometric standard deviation. A clip was placed on the nose and each aerosol was inhaled through the mouth by tidal breathing for $2 \mathrm{~min}$. Physiological saline was inhaled first, followed at 5-min intervals by histamine or methacholine in twofold increasing concentrations from 0.03 to $16 \mathrm{mg} / \mathrm{ml}$. The histamine solutions were made up as needed at intervals up to three months; methacholine solutions were renewed every two weeks.

The FEV 1 was measured using a Collins 13.5 1 water spirometer. Initially the manoeuvre was repeated until three reproducible values were obtained. After each inhalation it was measured at 0.5 and $1.5 \mathrm{~min}$ and, if necessary, at $3 \mathrm{~min}$ and subsequent intervals of 2 min to obtain the lowest post-inhalation $\mathrm{FEV}_{1}$. The $\mathrm{FEV}_{1}$ was measured only once on these occasions unless the measurement was technically unsatisfactory.

Inhalations were continued until the $\mathrm{FEV}_{1}$ had fallen by $20 \%$ or more. The change in $\mathrm{FEV}_{1}$ was calculated from the lowest post-saline value. Responses were expressed in terms of the provocative concentration of histamine or methacholine producing a $20 \%$ fall in $\mathrm{FEV}_{1}\left(\mathrm{PC}_{20}\right)$. This was obtained from the log dose-response curve.

\section{STUDY DESIGN}

All comparison tests were performed single-blind at the same time of day on separate days within one week. In each subjer $t$ the baseline $\mathrm{FEV}_{1}$ was required to be more than $70 \%$ of predicted and within $\pm 5 \%$ of values on the previous test day. Subjects were included only if they had had no respiratory infection or vaccination, no exposure to relevant allergens, and no salicylate ingestion for six weeks. Inhaled beta-adrenergic agonists and sodium cromoglycate were withheld for eight hours, ingested bronchodilators for 24 hours, and antihistamines for 48 hours before each study. Prednisone or beclomethasone dipropionate aerosol were continued in the same dose.

The short-term reproducibility of responses to histamine and to methacholine were investigated by performing two identical inhalation tests with each agent. Fourteen subjects (11 asthmatic, three normal) were tested with histamine, and another group of 13 subjects (11 asthmatic, two normal) were tested with methacholine.

Response to histamine and methacholine were $\stackrel{\overparen{D}}{2}$ compared in 33 asthmatic and 14 normal subjects $\%$ by performing one identical test with each agent. $\vec{\circ}$ Twenty-three of these subjects, with a $\mathrm{PC}_{20}$ of $1 \mathrm{mg} / \mathrm{ml}$ or above, completed a questionnaire re- $\vec{\omega}$ garding side effects after each test. The possibility $\stackrel{?}{\rightleftharpoons}$ of a cumulative dose effect produced by the $\vec{x}$ method was examined for histamine in 15 subjects $\underset{\omega}{\omega}$ (14 asthmatics, one normal) and for methacholine $\dot{\sigma}$ in a different group of 10 subjects (eight asthmatic, $\stackrel{\partial}{ }$ two normal). In each subject one test was carried 0

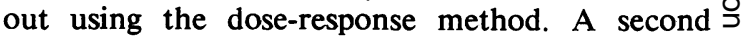
test was performed giving only the final concentra- $\overrightarrow{-}$ tion inhaled in the first test. The $\mathrm{PC}_{20}$ was obtained $\underset{\mathbb{D}}{ }$ for the first test as previously described; for the $\overparen{\Phi}$ second test it was calculated by the formula:

concentration of agent inhaled $\times 20$

$$
\% \text { fall in } \mathrm{FEV}_{1}
$$

\section{ANALYSIS}

Values of $\mathrm{PC}_{20}$ were compared using linear regression analysis and Student's paired $t$ test.

\section{Results}

There was a high degree of reproducibility of responses to histamine; the coefficient of determination $\left(r^{2}\right)$ was 0.994, (fig 1a). Responses to methacholine were also reproducible $\left(\mathrm{r}^{2}=0.990\right)$ (fig 1b).

There was a close correlation between the $\stackrel{\sim}{x}$ severity of responses to histamine and methacholine $\left(\mathrm{r}^{2}=0.85\right)$ (fig 2$)$.

Inhalation of at least three doubling concentrations of methacholine at intervals of $5 \mathrm{~min}$ pro-

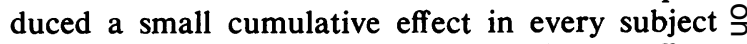
(fig 3a). For the group this was a significant effect $D$ $(P<0.01)$. By contrast, no cumulative effect was seen with histamine (fig $3 b$ ).

Dyspnoea, chest tightness, or wheezing occurred with equal frequency after both agents in associ- 0 ation with the fall in $\mathrm{FEV}_{1}$. Irritation of the throat $\omega$ and cough occurred alone or in association with headache or flushing more often with histamine than with methacholine; they were dose related $\mathbb{D}$ (fig 4). Among those subjects with "irritant" and? systemic symptoms, seven had a fall in $\mathrm{FEV}_{1}$ of ${ }_{0}$ less than $20 \%$ after inhalation of histamine $8 \mathrm{mg} / \stackrel{\vec{D}}{\stackrel{O}{D}}$ $\mathrm{ml}$. These seven were unable to tolerate histamine at $16 \mathrm{mg} / \mathrm{ml}$ but were able to tolerate methacho- $\stackrel{\mathbb{Q}}{\varrho}$ line up to $16 \mathrm{mg} / \mathrm{ml}$, allowing falls in $\mathrm{FEV}_{1}$ of greater than $20 \%$ to occur. 

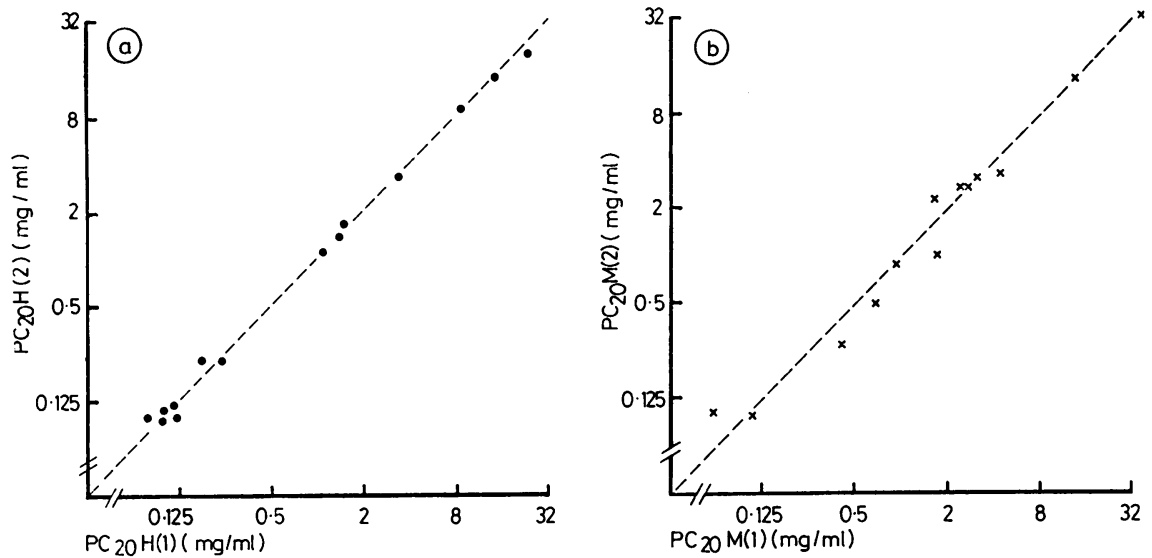

Fig 1 Reproducibility of responses to inhaled histamine (a) and methacholine $(b)$. $P C_{20} H$ (1) is $P C_{20}$ from first test with histamine; $P C_{20} H$ (2) is $P C_{20}$ from second; and $P C_{20} M(1)$ and $P C_{20} M(2)$ are corresponding symbols for methacholine. Dashed lines are lines of identity. Coefficient of determination $=0.994$ for histamine and 0.990 for methacholine.

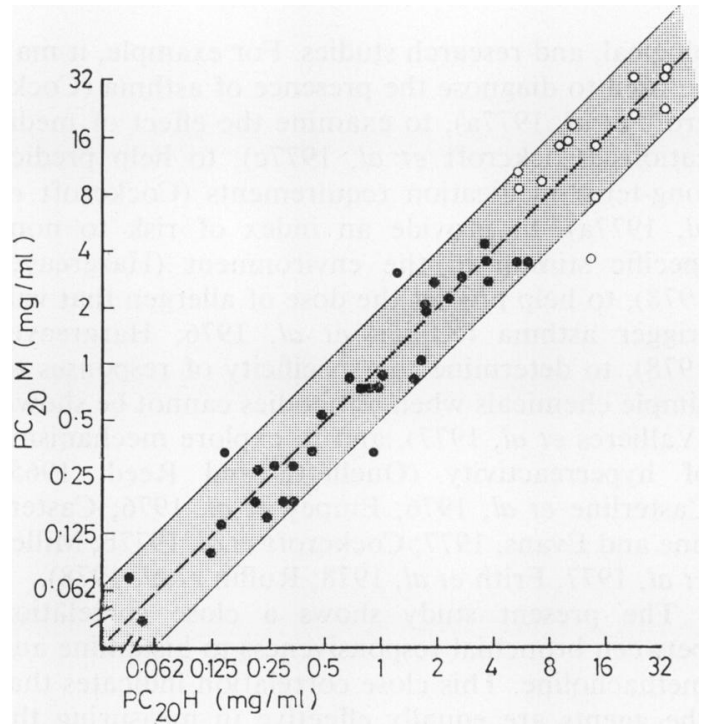

Fig 2 Comparison of responses to inhaled histamine and methacholine. Open circles represent normal subjects $(n=14)$ and closed circles asthmatics $(n=33)$. Cross-hatching indicates region of single twofold concentration difference. Dashed line is line of identity. Coefficient of determination $=0.85$.

\section{Discussion}

In this study we have shown that the inhalation test method is capable of inducing responses to histamine and methacholine that are highly reproducible in severity. This is a result of the careful standardisation of the method, which includes consistent generation of aerosol, inhalation by tidal breathing, the use of $\mathrm{FEV}_{1}$ as a measure of response, and the careful control of other factors known or presumed to influence the response. Nebuliser output and particle size are both important in relation to the consistent generation of aerosol. Nebuliser output varies considerably between nebulisers and is important to control (Mercer, 1973); particle size also varies between nebulisers, although between $1.3 \mu \mathrm{m}$ and $3.6 \mu \mathrm{m}$ it does not influence the response (Dolovich et al, 1978). The method of inhalation influences the dose reaching the lung and the pattern of deposition in the lung (Pavia et al, 1977). In the present study tidal breathing was used in preference to vital capacity inspirations because the latter influence lung mechanics (Gayrard et al, 1975; Fish et al, 1977) and produce more variability in lung dose and deposition pattern unless the speed of inspiration is carefully controlled (Pavia et al, 1977). Other "non-technical" factors that may influence the response and which were controlled include time of day (deVries et al, 1962), degree of initial airflow obstruction (Benson, 1975), respiratory infection (Empey et al, 1976) vaccination (Ouellette and Read, 1965), allergen exposure (Altounyan, 1971; Cockcroft et al, 1977b), smoking, and medications (Chai et al, 1975; Cockcroft et al, 1977c). Variation in the influence of these factors may alter bronchial responsiveness over longer periods.

The inhalation test method is simple and portable, and is therefore suitable for clinical, epidemi- 

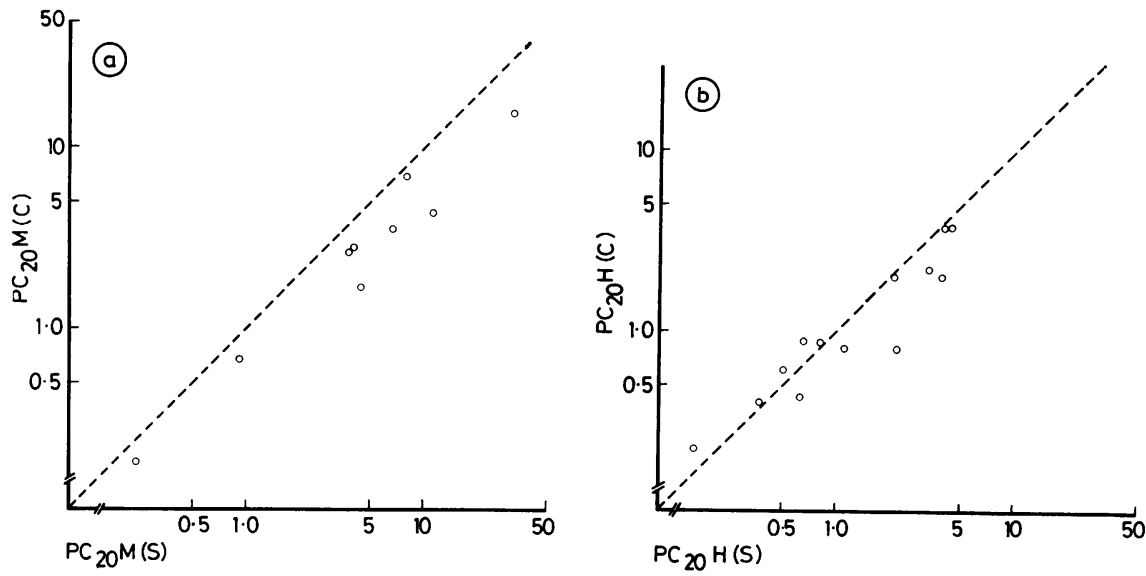

Fig 3 Cumulative dose effect of inhaled methacholine (a) and histamine (b). $P C_{20} H(c)$ is $P C_{30}$ calculated from standard dose-response inhalation test with histamine; $P C_{20} H(S)$ is $P C_{20}$ calculated from a single dose inhalation test with histamine; Same symbols are used for $P C_{20} M$. Dashed line is line of identity. Coefficient of determination=0.79 for histamine and 0.94 for methacholine.

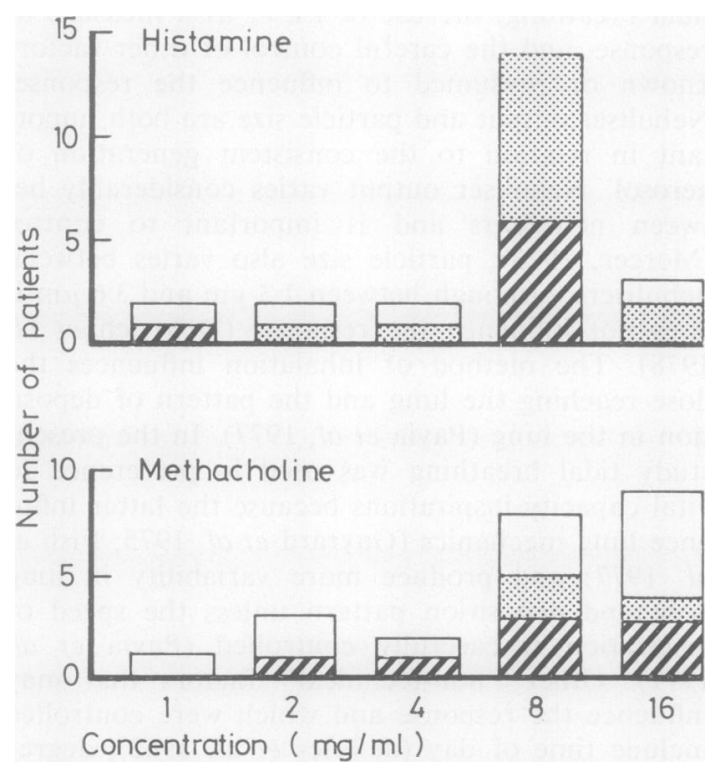

Fig 4 "Irritant" and systemic side effects from higher doses of inhaled histamine and methacholine. Concentration refers to final concentration tolerated by virtue either of $20 \%$ fall in FEV $V_{1}$ or of side effects. $\square$ Subjects with no symptoms; Subjects with throat irritation and coughing alone; and $\bigcirc$ Subjects with throat irritation and coughing, and headache or flushing. Mild irritant and systemic symptoms were more common with histamine. ological, and research studies. For example, it mays be used to diagnose the presence of asthma (Cock-o croft et al, 1977a), to examine the effect of medi-气 cations (Cockcroft et al, 1977c), to help predict $\mathscr{\Phi}^{\mathbb{Q}}$ long-term medication requirements (Cockcroft et $\overrightarrow{\vec{B}}$ $a l, 1977 \mathrm{a}$ ), to provide an index of risk to non- $\frac{3}{3}$ specific stimuli in the environment (Hargreave, 1978), to help predict the dose of allergen that willo trigger asthma (Killian et al, 1976; Hargreave, 1978), to determine the specificity of responses to음 simple chemicals when antibodies cannot be shown ${ }_{\times}$ (Vallières et al, 1977), and to explore mechanismso of hyperreactivity (Ouellette and Reed, 1965, Casterline et al, 1976; Empey et al, 1976; Caster- $\delta$ line and Evans, 1977; Cockcroft et al, 1977b; Miller $₹$ et al, 1977, Frith et al, 1978; Ruffin et al, 1978).

The present study shows a close correlation $>$ between bronchial responsiveness to histamine and을. methacholine. This close correlation indicates that $N$ the agents are equally effective in measuring the ${ }^{\circ}$ level of non-specific bronchial reactivity. The $\tilde{O}$ similarity in responsiveness also has implications ${ }_{\omega}^{N}$ in understanding the cause of the non-specifico bronchial hyperreactivity of asthma, which ato present remains unknown. One hypothesis is that there is a heightened sensitivity of irritant receptors? and a consequent exaggerated reflex cholinergic 0 bronchoconstriction (Nadel, 1977). The results of the present study suggest that this is not the only@ abnormality. Studies on the mechanism of action $\stackrel{\odot}{\Phi}$ of inhaled histamine in man indicate that it actso partly through reflex cholinergic pathways and partly by direct effects on histamine $H_{1}$ receptorso 
(Casterline et al, 1976; Casterline and Evans, 1977; Ruffin et al, 1978) and $\mathrm{H}_{2}$ receptors (Frith et al, 1978). By contrast methacholine is considered to have no effect on irritant receptors and to exert its effect through cholinergic receptors on smooth muscle (Goodman and Gilman, 1975; Miller et al, 1976). In the present study the similar severity of effects by agents with different mechanisms of action suggests that the primary cause of the hyperreactivity lies at the level of smooth muscle. Such an alternative hypothesis has already been suggested by Antonissen et al (1977) and Miller et al (1978).

In the present study inhalation of methacholine at 5-min intervals produced a cumulative effect, which was not seen with histamine. Histamine, however, produced more "irritant" and systemic side effects at higher doses. These differences between the effects of histamine and methacholine, which have been observed by others (Orehek and Gayrard, 1976), need to be taken into account when considering which agent to use in studies of non-specific reactivity. Other possible differences between the agents include the shelf life and the degree of change in reactivity after allergen exposure. The shelf life is not accurately known, but is probably longer for histamine (years) than methacholine (weeks) (Windholz, 1976). Changes in responsiveness to histamine after allergeninduced asthma are greater than changes in responsiveness to methacholine (Cockcroft et al, 1977b). The present study shows, however, that when factors that modify responses are controlled, either agent may be used with equal efficiency to show the level of non-specific bronchial reactivity.

We thank our subjects who participated in the study, Dr N L Jones, and Dr J Dolovich who helped review the manuscript, and Mrs Nancy Alder and Mrs Nancy Meerveld who typed the manuscript. Dr P A Frith is a fellow in respirology and allergy supported by Bencard Allergy Service, Weston, Ontario. Dr D W Cockcroft is a fellow of the Medical Research Council of Canada. The work was supported by Grant no MA 5888 of the Medical Research Council of Canada.

\section{References}

Altounyan, R E C (1971). In discussion in Identification of Asthma (Ciba Foundation Study Group, No 38) edited by $R$ Porter and J Birch, p 160. Churchill Livingston, Edinburgh and London.

Antonissen, L A, Mitchell, R W, Kromer, U, and Stephens, N (1977). Biophysical alterations in airway smooth muscle in a canine asthmatic model. Proceedings of the International Union of Physiological
Sciences, 13, 27.

Benson, M K (1975). Bronchial hyperreactivity. British Journal of Diseases of the Chest, 69, 227-239.

Casterline, C L, Evans, R, and Ward, G W jun (1976). The effect of atropine and albuterol aerosols on the human bronchial response to histamine. Journal of Allergy and Clinical Immunology, 58, 607-613.

Casterline, C L, and Evans, R (1977). Further studies on the mechanism of human histamine-induced asthma. The effect of an aerosolized $\mathrm{H}_{1}$ receptor antaongist (Diphenhydramine). Journal of Allergy and Clinical Immunology, 59, 420-424.

Chai, H, Farr, R S, Froehlich, L A, Mathison, D A, McLean, J A, Rosenthal, R R, Sheffer, A L, Spector, S L, and Townley, R G (1975). Standardization of bronchial inhalation challenge procedures. Journal of Allergy and Clinical Immunology, 56, 323-327.

Cockcroft, D W, Killian, D N, Mellon, J J A, and Hargreave, F E (1977a). Bronchial reactivity to inhaled histamine: a method and clinical survey. Clinical Allergy, 7, 235-243.

Cockcroft, D W, Ruffin, R E, Dolovich, J, and Hargreave, F E (1977b). Allergen-induced increase in non-allergic bronchial reactivity. Clinical Allergy, 7, 503-513.

Cockcroft, D W, Killian, D N, Mellon, J J A, and Hargreave, F E (1977c). Protective effect of drugs on histamine-induced asthma. Thorax, 32, 429-437.

deVries, K, Goei, J T, Booy-Noord, H, and Orie, N G M (1962). Changes during 24 hours in the lung function and histamine hyperreactivity of the bronchial tree in asthmatic and bronchitic patients. International Archive of Allergy, 20, 93-101.

Dolovich, M B, Obminski, G, Cockcroft, D W, Wolff, R, Hargreave, F E, and Newhouse M T (1978). Aspects of inhalation challenge testing: nebulizer output, particle size and inspiratory flow rate. In preparation.

Empey, D W, Laitinen, L A, Jacobs, L, Gold, W M, and Nadel, J A (1976). Mechanism of bronchial hyperreactivity in normal subjects after upper respiratory tract infection. American Review of Respiratory Disease, 113, 131-139.

Fish, J E, Peterman, V I, and Cugell, D W (1977). Effect of deep inspiration on airway conductance in subjects with allergic rhinitis and allergic asthma. Journal of Allergy and Clinical Immunology, 60, 41-46.

Frith, P A, Ruffin, R E, Oldenburg, F A, Newhouse, $M$ T, and Hargreave, F E (1978). Evidence for histamine ${ }_{2}\left(\mathrm{H}_{2}\right)$ receptors in asthmatic airways. Journal of Allergy and Clinical Immunology. Submitted for publication.

Gayrard, P, Orehek, J, Grimaud, C, and Charpin, J (1975). Bronchoconstrictor effects of a deep inspiration in patients with asthma. American Review of Respiratory Disease, 111, 433-440.

Goodman, L S, and Gilman, A (1975). The Pharmacological Basis of Therapeutics, 5th edn, p 594. MacMillan, New York.

Hargreave, F E. Non-specific airway reactivity in 
occupational pulmonary disease. In Occupational Pulmonary Disease: Focus on Grain Dust and Health, edited by J A Dosman and D J Cotton. Academic Press. In press.

Killian, D, Cockcroft, D W, Hargreave, F E, and Dolovich, J (1976). Factors in allergen-induced asthma; relevance of the intensity of the airways allergic reaction and non-specific bronchial reactivity. Clinical Allergy, 6, 219-225.

Mercer, T T (1973). Production and characterization of aerosols. Archives of Internal Medicine, 131, 3950.

Miller, M M, Patterson, R, and Harris, K E (1976). A comparison of immunologic asthma to two types of cholinergic respiratory responses in the rhesus monkey. Journal of Laboratory and Clinical Medicine, 88, 995-1007.

Miller, M M, Fish, J E, and Patterson, R (1977). Methacholine and physostigmine airway reactivity in asthmatic and non-asthmatic subjects. Journal of Allergy and Clinical Immunology, 60, 116-120.

Nadel, J A (1977). Autonomic control of airway smooth muscle and airway secretions American Review of Respiratory Disease, 115, Comroe Symposium, 117-126.

Orehek, J, and Gayrard, P (1976). Les tests de pro- vocation bronchique non-spécifiques dans l'asthme. Bulletin European Physiopathologie Respiratoire, 12, 565-598.

Ouellette, J J, and Reed, C E (1965). Increased response of asthmatic subjects to methacholine after influenza vaccine. Journal of Allergy, 36, 558-563.

Pavia, D, Thomson, M L, Clarke, S W, and Shannon, H S (1977). Effect of lung function and mode of inhalation on penetration of aerosol into the human lung. Thorax, 32, 194-197.

Ruffin, R E, Cockcroft, D W, Frith, P A, and Hargreave, F E. Effects of Sch 1000 and fenoterol against bronchoconstriction induced by histamine and methacholine. British Journal of Diseases of the Chest. Submitted for publication.

The Merck Index, edited by M Windholz (1976). 9th edn, item no 7666. Merck and Co, Rahway, NJ.

Vallières, M, Cockcroft, D W, Taylor, D M, Dolovich, J, and Hargreave, F E (1977). Dimethyl ethanolamine-induced asthma. American Review of Respiratory Disease, 115, 867-871.

Requests for reprints to: Dr F E Hargreave, Regional Chest and Allergy Unit, St Joseph's Hospital, 50 Charlton Avenue East, Hamilton, Ontario, Canada, L8N 1 Y4. 